\title{
DifFERENTIAL SUSCEPTIBILITY OF BIOTYPES OF Conyza sumatrensis TO Chlorimuron-ETHyl Herbicide ${ }^{1}$
}

\author{
Suscetibilidade Diferencial de Biótipos de Conyza sumatrensis ao Herbicida Chlorimuron-Ethyl
}

\author{
SANTOS, F.M. ${ }^{2}$, VARGAS, L. ${ }^{3}$, CHRISTOFFOLETI, P.J. ${ }^{4}$, AGOSTINETTO, D. ${ }^{5}$, MARIANI, F. ${ }^{5}$, and \\ DAL MAGRO, T. ${ }^{6}$
}

\begin{abstract}
Horseweed (Conyza spp.) is an annual weed, infesting soybean crops in southern Brazil, with chlorimuron-ethyl being one of the most commonly used herbicides for its control. However, in recent soybean harvests, an unsatisfactory control of this weed using this herbicide was observed, generating suspicion regarding the selection of resistant biotypes. The objective of this study was to evaluate the susceptibility of horseweed biotypes to the herbicide chlorimuron-ethyl. Two experiments were conducted in a greenhouse; in the first one, the biotypes were selected selected, and the second experiment was arranged in a $5 \times 5$ factorial in a completely randomized design with four replications. The treatments used in the preparation of the dose response curves were doses of the herbicide chlorimuron-ethyl $\left(0.0,1.56,3.13,6.25,12.5\right.$, and $\left.25 \mathrm{~g} \mathrm{ha}^{-1}\right)$, applied on the five horseweed biotypes at the 3-4 leaf growth stage. The variables evaluated were visual control percentage and shoot dry weight, compared to the control without herbicide application, and plant acetolactate accumulation. It was concluded that there is a differential susceptibility among the biotypes at doses of less than $20 \mathrm{~g} \mathrm{ha}^{-1}$ (dose response curves), which indicates low-level resistance. The practical consequences are the indications of chlorimuron-ethyl application at the maximum doses recomended and that the practice of rotating mechanisms of action must be used in the chemical weed management of these areas.
\end{abstract}

Keywords: chemical control, horseweed, low level resistance, ALS.

RESUMO - A buva (Conyza spp.) é uma planta daninha anual que infesta lavouras de soja na região Sul do Brasil, onde o chlorimuron-ethyl é um dos herbicidas mais utilizados para o seu controle. Contudo, nas últimas safras de soja observou-se controle insatisfatório dessa planta daninha utilizando esse herbicida, gerando a suspeita de seleção de biótipos resistentes. Assim, o objetivo deste trabalho foi avaliar a suscetibilidade de biótipos de buva ao herbicida chlorimuron-ethyl. Foram realizados dois experimentos em casa de vegetação: no primeiro, foram selecionados os biótipos; e o segundo foi realizado em esquema fatorial $5 \times 5$, no delineamento experimental inteiramente casualizado com quatro repetições. Os tratamentos usados na elaboração das curvas de doseresposta foram doses do herbicida chlorimuron-ethyl (0,0, 1,56, 3,13, 6,25, 12,5 e $\left.25 \mathrm{~g} \mathrm{ha}^{-1}\right)$, aplicadas sobre cinco biótipos de buva, no estádio fenológico de três a quatro folhas. As variáveis avaliadas foram percentagem visual de controle e fitomassa seca da parte aérea, em relação à testemunha sem aplicação de herbicida, e acúmulo de acetolactato na planta. Conclui-se que há suscetibilidade diferencial entre os biótipos nas doses menores que $20 \mathrm{~g} \mathrm{ha}^{-1}$ (curvas de doseresposta), e esse fato indica resistência de nivel baixo. As consequências práticas são a indicação da aplicação do herbicida chlorimuron-ethyl em doses máximas registradas e que a prática de rotação de mecanismos de ação seja usada no manejo quimico dessas áreas.

Palavras-chave: controle químico, buva, resistência de nível baixo, ALS.

Recebido para publicação em 2.10.2013 e aprovado em 25.12.2013.

2 Instituto Federal do Rio Grande do Sul, Sertão-RS, Brasil, <fernando.machado@sertao.ifrs.edu.br>; Embrapa Trigo, Passo Fundo-RS, Brasil; ${ }^{4}$ ESALQ/USP, Piracicaba-SP, Brasil; ${ }^{5}$ UFPel, Capão do Leão-RS, Brasil; 6 UCS, Caxias do Sul, RS, Brasil.

Planta Daninha, Viçosa-MG, v. 32, n. 2, p. 427-435, 2014 


\section{INTRODUCTION}

The Conyza gender includes approximately 50 species, which are distributed throughout most of the world (Kissmann and Groth, 1999). Often they occur in orchards, vineyards and other crops such as wheat, corn, soybeans and cotton, and also forage crops, pastures and uncultivated areas. The species Conyza bonariensis and $C$. sumatrensis are native to South America, occurring in Argentina, Uruguay, Paraguay and Brazil. Horseweed (Conyza spp.) is an annual plant that germinates in the fall / winter, ending its cycle in the summer; therefore, it is classified as a life cycle of winter and summer (Kissmann and Groth, 1999).

The species C. sumatrensis and C. canadensis are considered the most widespread worldwide (Thebaud and Abbott, 1995). This occurs due to propagation by seeds, which are produced in large quantities and easily dispersed by wind and water, depending on the pappus present in its achenes (Hao et al., 2009). Horseweed competes with crops for environmental resources (water, light, nutrients); a population of 150 plants $\mathrm{m}^{-2}$ of C. canadensis reduces by $83 \%$ the productivity of soybeans (Bruce and Kells, 1990).

Herbicides are the primary tool used to manage weeds in areas planted with annual crops. However, there has been the selection of resistant biotypes due to repeated herbicide implementation of the same mechanism of action, and the factors that influence selection are the intensity of herbicide use, the efficacy and persistence of the herbicide, the specificity of the herbicide regarding the mechanism of action, the pattern of emergence of weed, and the effectiveness of the alternative control methods to the chemical methods used in the area (Rubim, 1991). Therefore, the correct use of herbicides is associated with the use of different methods of control and, in the case of chemical control, implementation of products with different mechanisms of action to reduce the selection of resistant weeds.

In southern Brazil, the soybean is a major crop, and horseweed is the most important weed. The selection of horseweed in soybean crop occurred due to repeated use of glyphosate after the introduction of soybeans resistant to this herbicide, as found for C. bonariensis (Vargas et al., 2007; Moreira et al., 2007), C. canadensis (Moreira et al., 2007) and C. sumatrensis (Santos, 2012).

With the identification of resistance to glyphosate in biotypes of $C$. bonariensis and C. canadensis in the Brazilian state of Rio Grande do Sul, other herbicides have become associated with glyphosate for control of these species, including chlorimuron-ethyl. It acts in plants by inhibiting acetolactate synthase (ALS) and preventing the synthesis of valine, leucine and isoleucine amino acids, which stops protein synthesis, which, in turn, interferes with DNA synthesis and growth of the plant (Rodrigues and Almeida, 2011).

Worldwide, 129 species of weeds resistant to ALS inhibitors have been identified, 80 of the magnoliopsidas class and 49 from the liliopsidas class (Heap, 2013). In Brazil, 12 biotypes resistant to ALS inhibitors were identified, of which five were of multiple resistance to ALS inhibitors with other mechanisms of action of herbicides (Heap, 2013). For horseweed resistant to ALS inhibitors so far one case of $C$. bonariensis has been identified in Israel. As for C. canadensis, seven cases were identified, one of multiple resistance in Israel, four in the U.S., with two cases of multiple resistance, one in Poland, and one in Canada, with multiple resistance. For C. sumatrensis, Two cases of resistance to ALS have been identified in Brazil, being one of multiple resistance (Heap, 2013).

After identification of glyphosate-resistant horseweed in Rio Grande do Sul, the continued use of the chlorimuron-ethyl herbicide may have selected biotypes resistant to ALS inhibitors, since control of failures and reduction of the efficacy of this product on horseweed have been observed. Given this scenario, the objective of this study was to assess the susceptibility of biotypes of horseweed to the chlorimuron-ethyl herbicide.

\section{MATERIALS AND METHODS}

Two experiments were conducted in a greenhouse located in the municipality of Passo Fundo-RS (S 28 ${ }^{\circ} 15^{\prime} 46^{\prime \prime}$ and W 52 $2^{\circ} 4^{\prime} 24^{\prime \prime}$, at $684 \mathrm{~m}$ of altitude). In the first experiment 
were collected seeds of horseweed biotypes (Conyzaspp.) in the Brazilian cities of Almirante Tamandaré do Sul (two biotypes), Carazinho (three biotypes), Coqueiros do Sul (three biotypes), Não-Me-Toque (one biotype), Passo Fundo (two biotypes), Pontão (four biotypes), Tapejara (three biotypes), Tio Hugo (four biotypes) and Vila Langaro (three biotypes), located in the middle plateau of Rio Grande do Sul, in areas where control of horseweed was unsatisfactory with the implementation of chlorimuron-ethyl in the 2010/11 soybean crop. After collection, the seeds were cleaned and stored in a refrigerator at a temperature between 3 and $5{ }^{\circ} \mathrm{C}$.

The sowing of the biotypes was held on $5 / 7 / 2011$ in plastic cups (experimental units) with a capacity for $250 \mathrm{~mL}$, containing substrate comprising land, corrected according to chemical analysis, extracted from a soil classified as Red-Yellow Podzolic. After the emergence, which occurred seven days after sowing (DAS), thinning was conducted, leaving two plants per cup.

The experimental design was completely randomized with four replications. The treatments assessed in the first experiment were: glyphosate (720 g e.a. ha-1), chlorimuronethyl $\left(0.0 ; 6.25 ; 12.5\right.$; and 25.0 g i.a. ha $\left.{ }^{-1}\right)$ and the association of glyphosate (720 g e.a. ha-1) + chlorimuron-ethyl (6.25, 12.5 and 25.0 g i.a. ha ${ }^{-1}$ ), totaling eight treatments; these doses were considered discriminatory for the selection of susceptible contrasting biotypes for the next stage of the work, which characterized the biotypes through doseresponse curves. The implementation of the treatments was done on $15 / 6 / 2011$, when horseweed plants reached the 3-4 leaf stage, using a backpack sprayer pressurized by $\mathrm{CO}_{2}$, equipped with Teejet XR 115.02 tips of the fan type, spaced $0.5 \mathrm{~m}$, with a spray volume of $150 \mathrm{~L} \mathrm{ha}^{-1}$ and work pressure of $1.62 \mathrm{kgf} \mathrm{cm}^{-2}$. Three visual control assessments (\%) were made at 15,30 and 45 days after the implementation of the treatments (DAT), whose data are not presented in this paper.

In the second experiment, the five biotypes of horseweed selected from the first experiment were assessed, in a $5 \times 5$ factorial design; the biotypes were designated 1, 17 and 20 , considered with lower sensitivity level, and of 2 and 8, considered of higher sensitivity to the chlorimuron-ethyl herbicide. The geographical location of the site where they were collected is in Table 1. The methodology of sowing and treatments spraying was the same used in the first experiment. The treatments assessed in this experiment were doses of chlorimuron-ethyl $(0.0 ; 1.56 ; 3.13$; 6.25; and $12.5 \mathrm{~g} \mathrm{ha}^{-1}$ ).

The variables assessed were visual control (\%) and shoot dry weight $\left(\mathrm{g} \mathrm{ha}^{-1}\right)$ of the shoots of the plant, compared to untreated plants. For biotypes 2, 17 and 20 the enzymatic properties of ALS were assessed, following the methodology adopted by Dal Magro et al. (2010).

Assessments were made visually by two evaluators at 7, 14 and 21 DAT (days

Table 1 - Identification of sampling sites of Conyza spp. biotypes used in the dose-response curves to the chlorimuron-ethyl herbicide. Passo Fundo RS, 2011

\begin{tabular}{|c|c|c|}
\hline Code & City & \multicolumn{1}{c|}{ Coordinates } \\
\hline Biotype 1 & Pontão & $\begin{array}{l}\text { Latitude: } 28^{\circ} 01^{\prime} 30.10^{\prime \prime} \mathrm{N} \\
\text { Longitude: } 52^{\circ} 46^{\circ} 22.20^{\prime \prime} \mathrm{E}\end{array}$ \\
\hline Biotype 2 & Pontão & $\begin{array}{l}\text { Latitude: } 28^{\circ} 00^{\prime} 20.40^{\prime \prime} \mathrm{N} \\
\text { Longitude: } 52^{\circ} 45^{\prime} 12.40^{\prime \prime} \mathrm{E}\end{array}$ \\
\hline Biotype 8 & Coqueiros do Sul & $\begin{array}{l}\text { Latitude: } 28^{\circ} 11^{\prime} 45.50^{\prime \prime} \mathrm{N} \\
\text { Longitude: } 52^{\circ} 34^{\circ} 44.12^{\prime \prime} \mathrm{E}\end{array}$ \\
\hline Biotype 17 & Coqueiros do Sul & $\begin{array}{l}\text { Latitude: } 28^{\circ} 07^{\prime} 28.00^{\prime \prime} \mathrm{N} \\
\text { Longitude: } 52^{\circ} 42^{\prime} 47.90^{\prime \prime} \mathrm{E}\end{array}$ \\
\hline Biotype 20 & Tio Hugo & $\begin{array}{l}\text { Latitude: } 28^{\circ} 18^{\prime} 06.51^{\prime \prime} \mathrm{N} \\
\text { Longitude: } 52^{\circ} 53^{\prime} 41.31^{\prime \prime} \mathrm{E}\end{array}$ \\
\hline
\end{tabular}


after treatment implementation), using a percentage scale, where 0 represented no symptoms and 100 represented the death of plants (Frans et al., 1986). After the final assessment, at 21 DAT, harvesting the plants was performed in order to determine the production of shoot dry weight. For this, the plant material was submitted to drying in a forced air circulation greenhouse at $60^{\circ} \mathrm{C}$ until a constant weight was obtained and then weighed. The weight values became percentage, comparing the dry weight obtained in treatments with herbicide with the average dry matter obtained in the control, considered $100 \%$.

The data obtained were analyzed for normality (Shapiro-Wilk test) and subsequently subjected to analysis of variance $(\mathrm{p} \leq 0.05)$. In the case of statistical significance being found, the regression analysis for the dose factor and the biotype factor was performed, obtaining the equations. Regression analysis was performed using the SigmaPlot 10.0 software (Sigmaplot, 2007), adjusting the data to a logistic type sigmoidal regression equation proposed by Streibig (1988):

$$
y=a /\left[1+(x / b)^{c}\right]
$$

where: $y=$ percentage of control or the shoot dry weight or enzyme activity ALS; $x=$ dose of the herbicide; and $a, b$ and $c$ are parameters of the curve, so that $a$ is the difference between the maximum and minimum points of the curve, $b$ is the dose that provides the percentage of $50 \%$ of response of the variable and $c$ is the slope of the curve. From the equations were determined the $\mathrm{C}_{50}, \mathrm{GR}_{50}$ and $I_{50}$ (necessary dose to obtain $50 \%$ of control or to reduce $50 \%$ of the weight of the shoots of the plant or inhibition of $50 \%$ of the ALS enzyme activity, compared to untreated plants, respectively) and the confidence intervals. Finally, the resistance factor (FR) was obtained, dividing $\mathrm{C}_{50}, \mathrm{GR}_{50}$ and $\mathrm{I}_{50}$ of the biotypes by the said value of the most sensitive biotype.

For biotypes 2 (susceptible), 17 and 20 (less sensitive to chlorimuron-ethyl), exsiccated specimens were prepared and sent to the Department of Biology of the federal university Universidade Federal de Santa Maria, where they were cataloged and classified by Dr. Thais Scotti do Canto Dorow as Conyza sumatrensis
(Teles et al., 2013), being deposited in the herbarium under numbers SMDM 13950, SMDM 13952 and SMDM 13953.

\section{RESULTS AND DISCUSSION}

In the first trial, it was observed that all biotypes of horseweed were efficiently controlled $(100 \%)$ at a dose of $20 \mathrm{~g} \mathrm{ha}^{-1}$ of chlorimuron-ethyl (data not shown). However, different levels of sensitivity among biotypes and in response to discriminatory doses of tested chlorimuron-ethyl were observed; in the lowest dose assessed, biotypes 1, 17 and 20 showed minimal sensitivity, while the biotypes 2 and 8 were controlled.

Differences in sensitivity may characterize low-level resistance, which occurs when there is a difference in control between resistant and susceptible biotypes at doses below the one recorded, but in the dose of registration of the herbicide the biotypes are controlled. What happens in practice is the reduction of the sensitivity of the biotypes to herbicides, but they continue to be controlled with the registered dose (indicated in the package insert) and are not therefore classified as resistant. In such cases, one can consider the possibility that the biotypes are evolving into resistance if the selection pressure imposed by the herbicide continues to be practiced in the area. Moreover, no increase was observed in the control of biotypes when combining glyphosate with chlorimuron. This is possibly due to the fact that these biotypes are resistant to glyphosate.

In order to test the hypothesis of low-level resistance, there was the second experiment trying to characterize, by means of doseresponse curves, the behavior of the biotypes when treated with doses of chlorimuron-ethyl below the highest recorded dose, which is $20 \mathrm{~g} \mathrm{ha}^{-1}$ (Rodrigues and Almeida, 2011). The results indicated that the biotypes of Conyza spp. exhibit different responses and with the same standard at doses of the chlorimuron-ethyl herbicide assessed at 7, 14 and 21 DAT (Figure 1).

In the assessment performed at $7 \mathrm{DAT}$, considering $12.5 \mathrm{~g} \mathrm{ha}^{-1}$ the highest dose applied, it was observed that the highest level of control was evidenced by biotype 2 (65\%), 

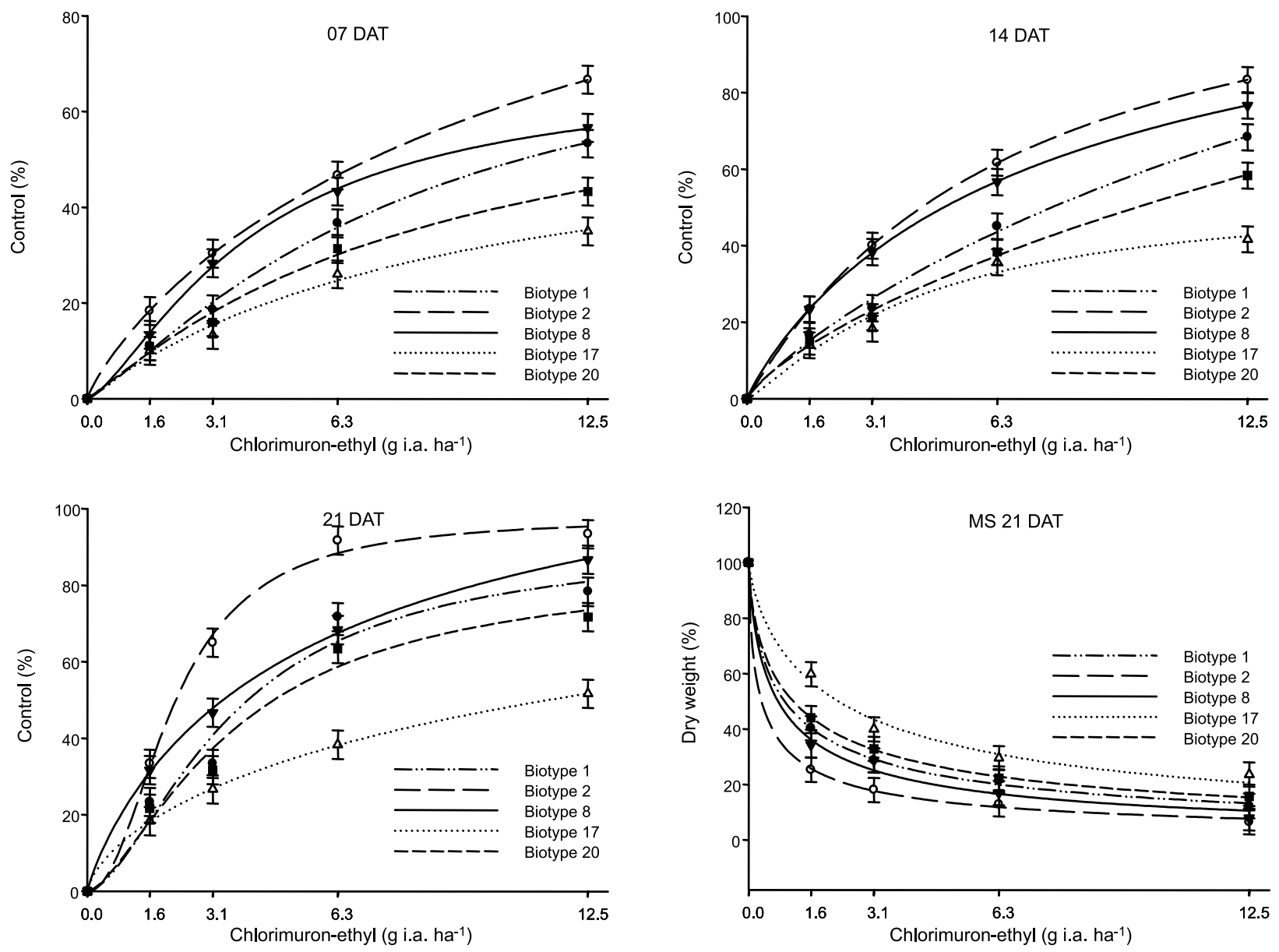

The vertical bars represent 95\% of confidence interval. Passo Fundo RS, 2011, DAT = days after the herbicide treatment.

Figure 1 - Visual control percentage (\% control) and percentage of dry weight (FMS) of the shoots at the dose of 0.0 of chlorimuronethyl in five Conyza spp. biotypes, due to the implementation of different doses of this herbicide, assessed at 7, 14 and 21 days after treatment (DAT).

while biotypes 1 and 8 showed approximately $55 \%$ of control. As for biotypes 17 and 20, they showed a control level of 40 and $50 \%$, respectively (Figure 1). In the assessment done at 14 DAT, the largest control was again observed in biotype $2(80 \%)$, while biotypes 1 , 8 and 20 evidenced control between 55 and $75 \%$. Biotype 17 showed again the lowest control: approximately 40\% (Figure 1). In the last assessment, done at $21 \mathrm{DAT}$, the greatest control was observed in biotypes 2 and 8, above $80 \%$, while biotypes 1 and 20 showed control between 70 and $80 \%$. Biotype 17 showed again the lowest control: approximately 50\% (Figure 1).

In the values of the determination coefficient $\left(R^{2}\right)$ varied from 0.97 to 0.99 , demonstrating adjustment to the model (Table 2). From the regression equations, the values of $\mathrm{C}_{50}$ for the selected biotypes were calculated and, from them, the resistance factors (FR). With the lack of overlap of the confidence interval (CI) of the most sensitive biotype (biotype 2) in relation to the IC of the other biotypes, it was possible to establish the resistance factor for all assessment periods of control, but not for all biotypes.

Considering the assessment done at 7 DAT, it is observed for biotypes 17 and 20 the necessary dose to control $50 \%$ of the population was above $12.5 \mathrm{~g} \mathrm{ha}^{-1}$ os chlorimuron-ethyl; thus, it was possible to determine the $\mathrm{C}_{50}$ and hence the confidence interval. Regarding biotype 8, there was an 
Table 2 - Equations of control, values of $\mathrm{C}_{50}$ with confidence intervals (IC) and resistance factor (FR) of five biotypes of Conyza spp., in response to the implementation of doses of the chlorimuron-ethyl herbicide at 7, 14 and 21 days after treatment (DAT). Passo Fundo RS, 2011

\begin{tabular}{|c|c|c|c|c|c|}
\hline \multirow{2}{*}{ Biotype } & \multirow{2}{*}{ 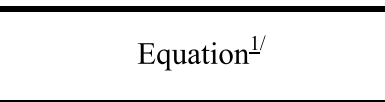 } & \multirow{2}{*}{$\mathrm{R}^{2}$} & \multicolumn{2}{|c|}{$\mathrm{C}_{50}{ }^{\frac{2}{\prime}}$} & \multirow{2}{*}{$\mathrm{FR}^{3}$} \\
\hline & & & $\mathrm{g} \mathrm{ha}^{-1}$ & $95 \%$ IC & \\
\hline \multicolumn{6}{|c|}{ Control 07 DAT } \\
\hline 1 & $\mathrm{y}=84.59 /\left[1+(\mathrm{x} / 8.03)^{-1.23}\right]$ & 0.99 & 10.84 & $8.0-13.7$ & 1.54 \\
\hline 2 & $\mathrm{y}=138.61 /\left[1+(\mathrm{x} / 13.65)^{-0.87}\right]$ & 0.99 & 7.05 & $6.2-7.92$ & - \\
\hline 8 & $\mathrm{y}=68.16 /\left[1+(\mathrm{x} / 4.11)^{-1.42}\right]$ & 0.99 & 8.41 & $7.9-8.96$ & NS \\
\hline 17 & $\mathrm{y}=61.23 /\left[1+(\mathrm{x} / 9.2)^{-1.01}\right]$ & 0.98 & IFG & - & - \\
\hline 20 & $\mathrm{y}=71.59 /\left[1+(\mathrm{x} / 8.36)^{-1.11}\right]$ & 0.99 & IFG & - & - \\
\hline \multicolumn{6}{|c|}{ Control 14 DAT } \\
\hline 1 & $\mathrm{y}=217.17 /\left[1+(\mathrm{x} / 30.18)^{-0.88}\right]$ & 0.99 & 7.62 & $4.62-10.6$ & 1.75 \\
\hline 2 & $\mathrm{y}=125.15 /\left[1+(\mathrm{x} / 6.44)^{-1.04}\right]$ & 0.99 & 4.36 & $4.14-4.58$ & - \\
\hline 8 & $\mathrm{y}=125.61 /\left[1+(\mathrm{x} / 7.69)^{-0.92}\right]$ & 0.99 & 4.92 & $4.21-5.63$ & NS \\
\hline 17 & $\mathrm{y}=54.23 /\left[1+(\mathrm{x} / 4.35)^{-1.22}\right]$ & 0.98 & IFG & - & - \\
\hline 20 & $\mathrm{y}=281.39 /\left[1+(\mathrm{x} / 69.74)^{-0.78}\right]$ & 0.99 & 9.74 & $7.27-12.2$ & 2.23 \\
\hline \multicolumn{6}{|c|}{ Control 21 DAT } \\
\hline 1 & $\mathrm{y}=90.94 /\left[1+(\mathrm{x} / 3.55)^{-1.6570}\right]$ & 0.97 & 4.02 & $1.75-6.29$ & 1.81 \\
\hline 2 & $\mathrm{y}=97.58 /\left[1+(\mathrm{x} / 2.16)^{-2.1282}\right]$ & 0.99 & 2.22 & $1.78-2.26$ & - \\
\hline 8 & $\mathrm{y}=132.64 /\left[1+(\mathrm{x} / 6.01)^{-0.88}\right]$ & 0.99 & 3.40 & $0.44-6.36$ & NS \\
\hline 17 & $\mathrm{y}=125.01 /\left[1+(\mathrm{x} / 20.85)^{-0.68}\right]$ & 0.99 & 11.51 & $8.46-14.6$ & 5.18 \\
\hline 20 & $\mathrm{y}=84.96 /\left[1+(\mathrm{x} / 3.68)^{-1.51}\right]$ & 0.98 & 4.67 & $2.30-7.04$ & 2.10 \\
\hline
\end{tabular}

${ }_{1}^{1 /} \mathrm{y}=\mathrm{a} /\left[1+(\mathrm{x} / \mathrm{b})^{\mathrm{c}}\right] ;{ }^{2} / \mathrm{C}_{50}=$ dose necessary to obtain $50 \%$ of control; ${ }^{3 /}$ Factor of resistance to the chlorimuron-ethyl herbicide of the biotypes of Conyza spp., obtained from the division of the $\mathrm{C}_{50}$ of the biotypes related to the biotype of greatest sensitivity to chlorimuronethyl (2); IFG = value outside the interval of doses used in the experiment $\left(>12.5 \mathrm{~g}\right.$ i.a. ha $^{-1}$ of chlorimuron-ethyl); NS $=$ overlap of the confidence interval of the biotype of greater sensitivity (2) related to the biotype assessed shows that there was no significant difference between $\mathrm{C}_{50}$ of the biotypes.

overlapping of its IC with the one of biotype 2 (the more sensitive), i.e., the $\mathrm{C}_{50}$ of these biotypes was similar (Table 2). Biotype 1 showed FR of 1.54, i.e., the dose necessary to control $50 \%$ of the population of biotype 1 is 1.54 times treater than the one necessary to control biotype 2 (Table 2).

In the assessment done at 14 DAT, only for biotype 17 the dose necessary to control $50 \%$ of the population was above $12.5 \mathrm{~g} \mathrm{ha}^{-1}$ of chlorimuron-ethyl, and it was not possible to determine the confidence interval, while the $\mathrm{C}_{50}$ of biotypes 2 and 8 did not differ. For biotypes 1 and 20, the FR were of 1.75 and 2.23, respectively (Table 2 ).

In the last assessment, done at 21 DAT, the $\mathrm{C}_{50}$ of biotypes 2 and 8 did not differ again. For biotypes 1, 17 and 20, the FR were 1.81, 5.18 and 2.10, respectively, showing that the dose necessary to control $50 \%$ of the population of biotype 17 is 5.18 times greater than the one necessary for biotype 2 (Table 2 ).

The variable dry mass allowed the determination of the $\mathrm{GR}_{50}$ (Table 3 ). The values of the $\mathrm{GR}_{50}$ for biotypes 1,17 and 20 were of $0.9,2.24$ and $1.1 \mathrm{~g}$ i.a. ha ${ }^{-1}$ of chlorimuronethyl, respectively. Considering the values of $\mathrm{FR}$, equally to the one observed in the variable $\mathrm{C}_{50}$, biotype 17 showed the lowest sensitivity to the chlorimuron-ethyl herbicide and biotype 2 , the greatest (Tables 2 and 3 ).

This variation between $\mathrm{C}_{50}$ of biotypes 17 and 2 may be related to management practices or genetic characteristics, since the biotypes differ in their place of origin (Table 1). Some agricultural practices - such as the use of herbicides as the sole method of control; repeated implementation of the same herbicide or herbicides with the same mechanism of action; production systems that 
Table 3 - Equations of shoot dry weight, values of $\mathrm{GR}_{50}$ with confidence intervals (IC) and resistance factor (FR) of five biotypes of Conyza spp., in response to the implementation of doses of the chlorimuron-ethyl herbicide at 21 days after treatment (DAT). Passo Fundo RS, 2011

\begin{tabular}{|c|c|c|c|c|c|}
\hline \multirow{2}{*}{ Biotype } & \multirow{2}{*}{ Equation $^{1 /}$} & \multirow{2}{*}{$\mathrm{R}^{2}$} & \multicolumn{3}{|c|}{$\mathrm{GR}_{50}{ }^{2 /}$} \\
\cline { 3 - 6 } & & & $\mathrm{FR}^{3 /}$ \\
\hline 1 & $\mathrm{y}=99.99 /\left[1+(\mathrm{x} / 0.9)^{0,72}\right]$ & 0.99 & 0.90 & $0.78-1.02$ & 2.81 \\
\hline 2 & $\mathrm{y}=99.99 /\left[1+(\mathrm{x} / 0.33)^{0,68}\right]$ & 0.99 & 0.32 & $0.20-0.44$ & - \\
\hline 8 & $\mathrm{y}=99.94 /\left[1+(\mathrm{x} / 0.74)^{0,75}\right]$ & 0.99 & 0.73 & $0.35-1.11$ & $\mathrm{NS}$ \\
\hline 17 & $\mathrm{y}=100.22 /\left[1+(\mathrm{x} / 2.23)^{0,7824}\right]$ & 0.99 & 2.24 & $1.63-2.85$ & 7.00 \\
\hline 20 & $\mathrm{y}=100.01 /\left[1+(\mathrm{x} / 1.12)^{0,7073}\right]$ & 0.99 & 1.1 & $1.03-1.17$ & 3.44 \\
\hline
\end{tabular}

${ }_{1}^{1 /} \mathrm{y}=\mathrm{a} /\left[1+(\mathrm{x} / \mathrm{b})^{\mathrm{c}}\right] ;{ }^{2} \mathrm{GR}_{50}=$ dose necessary to obtain $50 \%$ of reduction of the shoot dry matter; ${ }^{3 /}$ Factor of resistance to the chlorimuronethyl herbicide of the biotypes of Conyza spp., obtained from the division of the $\mathrm{GR}_{50}$ of the biotypes related to the biotype of greatest sensitivity to chlorimuron-ethyl (2); IFG = value outside the interval of the chart studied ( $>12.5 \mathrm{~g}$ i.a. ha $^{-1}$ of chlorimuron-ethyl); NS $=$ overlap of the confidence interval of the biotype of greater sensitivity (2) related to the biotype assessed shows that there was no significant difference between $\mathrm{GR}_{50}$ of the biotypes.

do not use crop rotation and / or herbicides and non-disposal of plants out of control - tend to favor the selection of resistant or tolerant weeds (Christoffoleti et al., 2008).

The genetic characteristics between species can influence their response to herbicides (Vargas et al., 2011). The insensitivity of weeds to herbicides may result from the difficulty of absorption of the product, due to characteristics of the leaf blade, such as roughness, hairiness and chemical composition of the epicuticular wax (Sanchotene et al., 2008).

The main potential leaf barriers to penetration of herbicides in Conyza bonariensis are high trichome density, thick cuticle of the adaxial side, low stomatal density on the adaxial surface and presence of epicuticular wax, especially adaxially (Procópio et al., 2003). Thus, it is likely that these characteristics present in the leaves of Conyza spp. can intercept the droplets and reduce the absorption of the herbicide. Factors related to growth stage and weather conditions before, during and after herbicide implementation can alter the response of weeds to herbicides (Christoffoleti et al., 2008).

The in vitro activity of the ALS enzyme, extracted from biotypes 2, 17 and 20, showed values of $\mathrm{I}_{50}$ of $0.0002,0.0027$ and $0.0004 \mu \mathrm{M}$, respectively, resulting in FR of 13.5 for biotype 17 and of 2.0 for biotype 20 (Figure 2).

The kinetic parameters of the ALS enzyme showed no significant change in affinity of the enzyme for the substrate $\left(\mathrm{K}_{\mathrm{M}}\right)$ or enzyme efficiency $\left(\mathrm{V}_{\max }\right)$ for biotypes 2, 17 and 20. Research conducted with ALS of $E$. heterophyla (Vargas et al., 1999), Lactuta serriola (Eberlein et al., 1997) and Scirpus juncoides (Tanaka, 2003) showed similar results, in which the kinetics of the enzyme of the biotype resistant to the inhibiting herbicide of ALS was not altered.

In most cases of weed resistance to ALSinhibiting herbicides, the mechanism of resistance is due to the change in ALS in the site of action of the herbicide, which makes it insensitive (Dal Magro et al., 2010; Yu et al., 2010; Bozic et al., 2012). Changes in the site of action of the herbicide commonly result from mutations in the genes encoding the enzyme (Devine and Shukla, 2000), resulting in reduced affinity of the enzyme with the inhibitors (herbicides), but with no or little loss of enzyme function (Tranel and Wright, 2002). In the case of biotype 17 , there was a reduction of inhibition of ALS by chlorimuron herbicide with no effect on its kinetic properties. As for biotypes 2 and 20, they had the ALS activity equally inhibited by chlorimuron (Figure 2). It is likely that there has been some change in the ALS enzyme of biotype 17, which resulted in lower sensitivity to chlorimuron, as noted by Tranel and Wright (2002).

According to the criteria for official statistical reports of weed biotypes resistant to herbicides, a high level of resistance is classified when FR e" 10 (Gazziero et al., 2009). 


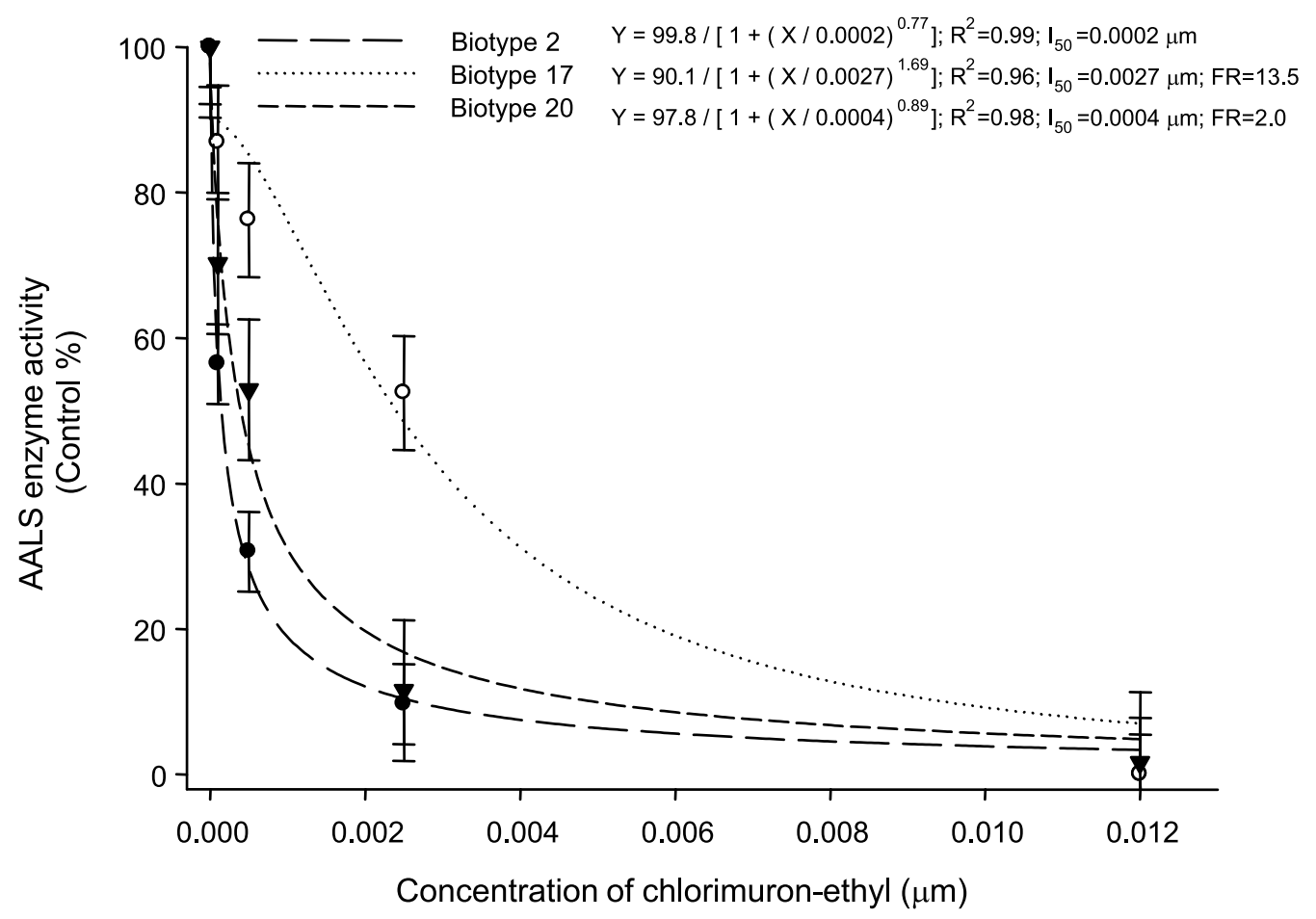

$\mathrm{I}_{50}=$ concentration of chlorimuron-ethyl necessary to inhibit $50 \%$ of the ALS enzyme activity. FR = factor of resistance calculated by the division of the $\mathrm{I}_{50}$ of the resistant biotype by the one corresponding to the susceptible biotype.

Figure 2 - Percentage of reduction in the synthase acetolactate enzyme activity (ALS) in vitro, as a function of doses of the chlorimuron-ethyl herbicide in three biotypes of $C$. sumatrensis $(2,17$ and 20). The points represent the mean values of the replicates, and the vertical bars, 95\% of confidence interval. Passo Fundo, RS, 2011.

The $\mathrm{I}_{50}$ of biotype 17 was 13.5 times higher than the one of biotype 2 , in view of the criteria to be considered resistant; yet, the dose of control of biotype 17 is below the one recorded, as observed in the first study in this work, which leads the resistance of biotype 17 to be classified as low-level. Horseweed has always been controlled efficiently by different ALS inhibitors and is not considered an originally tolerant species to these herbicides.

In summary, all assessed biotypes of Conyza spp. were efficiently controlled with the dose of $20 \mathrm{~g} \mathrm{ha}^{-1}$ of chlorimuron-ethyl, which discards the possibility of resistance. However, there is a difference in the levels of sensitivity among biotypes of horseweed in response to smaller doses than $20 \mathrm{~g}$ i.a. ha- ${ }^{-1}$ of chlorimuron-ethyl. The $\mathrm{I}_{50}$ of biotypes 2,17 and 20 was of $0.0002,0.0027$ and $0.0004 \mu \mathrm{M}$ of chlorimuron, respectively, and changes in kinetic parameters $\left(\mathrm{K}_{\mathrm{M}}\right.$ and $\left.\mathrm{V}_{\max }\right)$ of the ALS enzyme were not observed. Biotype 17 showed
FR of 13.5, showing low level resistance to chlorimuron. Thus, failures of control of Conyza sumatrensis observed in the fields of Rio Grande do Sul may have resulted from improper cultural practices such as: use of a dose of chlorimuronethyl herbicide below that indicated on the product label and / or implementation in advanced vegetative stage and / or failures in implementation technology.

The results of this study allow us to suggest that in situations in which the chlorimuronethyl is used in combination with glyphosate for control of horseweed populations resistant to glyphosate, their dose should be the maximum recommended $\left(20 \mathrm{~g} \mathrm{ha}^{-1}\right)$ and that the implementation should be made when the horseweed is in the vegetative stage of three to four leaves. Otherwise, these populations will be selected with great possibility to become resistant in the future, due to the intensive use of ALS-inhibiting herbicides to control horseweed resistant to glyphosate. 


\section{LITERATURE CITED}

BOZIC, D. et al. Resistance of sunflower hybrids to imazamox and tribenuron-methyl. Crop Protec., v. 39, n. 1, p. 1-10, 2012.

BRUCE, J.; KELLS, J. Horseweed (C. canadensis) control in no-tillage soybeans (Glycine max) with preplant and preemergence herbicides. Weed Technol., v. 4, n. 3, p. $642-647,1990$.

CHRISTOFFOLETI, P. J. et al. Aspectos de resistência de plantas daninhas a herbicidas. 3. ed. Piracicaba: Associação Brasileira de Ação a Resistência de Plantas aos Herbicidas HARAC-BR, 2008. 120 p.

DAL MAGRO, T. et al. Propriedades enzimáticas da enzima ALS de Cyperus difformis e mecanismo de resistência da espécie ao herbicida pyrazosulfuron-ethyl. Ci. Rural, v. 40, n. 12, p. 2439-2445, 2010.

DEVINE, M. D.; SHUKLA, A. Altered target sites as a mechanism of herbicide resistance. Crop Protec., v. 19, n. 8, p. 881-889, 2000.

EBERLEIN, C. V. et al. Altered acetolactate synthase activity in ALS-inhibitor resistant prickly lettuce (Lactuca serriola).

Weed Sci., v. 45, n. 2, p. 212-217, 1997.

FRANS, R. et al. Experimental design and techniques for measuring and analyzing plant responses to weed control practices. In: CAMPER, N. D. Research methods in weed science. 3. ed. Champaign: Southern Weed Science Society, 1986. p. 29-46.

GAZZIERO, D. L. P. et al. Critérios para relatos oficiais estatísticos de biótipos de plantas daninhas resistentes a herbicidas. In: AGOSTINETTO, D.; VARGAS, L. (Ed.). Resistência de plantas daninhas a herbicidas no Brasil. Passo Fundo: Berthier, 2009. p. 91-101.

HAO, J. H. et al. Reproductive traits associated with invasiveness in Conyza sumatrensis. J. Syst. Evol., v. 47, n. 3, p. 245-254, 2009.

HEAP, I. International survey of resistant weeds. Disponível em: $<\mathrm{http}: /$ www. weedscience.org $>$. Acesso em: 20 fev. 2013.

KISSMANN, K. G.; GROTH, D. Plantas infestantes e nocivas. 2. ed. São Paulo: BASF, 1999. v. 2. 978 p.

MOREIRA, M. S. et al. Resistência de Conyza canadensis e C. bonariensis ao herbicida glyphosate. Planta Daninha, v. 25, n. 1, p. 157-164, 2007.

PROCÓPIO, S. O. et al. Estudos anatômicos de folhas de espécies de plantas daninhas de grande ocorrência no brasil. III - Galinsoga parviflora, Crotalaria incana, Conyza bonariensis e Ipomoea cairica. Planta Daninha, v. 21, n. 1, p. 1-9, 2003.
RODRIGUES, B. N.; ALMEIDA, F. S. Guia de herbicidas. 6.ed. Londrina: 2011. 696 p.

RUBIM, B. Herbicide resistance in weeds and crops, progress and prospects. In: CASELEY, J. C.; CUSSANS, G. W.; ATKIN, R. K. Oxford: Butterworth-Heinemann, 1991. p. $387-414$.

SANCHOTENE, D. M. et al. Manejo químico de plantas daninhas tolerantes ao glyphosate na cultura da soja. R. Fac. Zootec. Veter. Agron., v. 15, n. 2, p. 77-84, 2008.

SANTOS, G. Resistência múltipla ao glyphosate e ao chlorimuron-ethyl em biótipos de Conyza sumatrensis. 2012. 87 f. Dissertação (Mestrado em Produção de Plantas) Universidade Estadual de Maringá, Maringá, 2012.

SIGMAPLOT - Scientific Graphing Software. Version 10.0, 2007.

STREIBIG, J. C. Herbicide bioassay. Weed Res., v. 28, n. 1, p. 479-484, 1988.

TANAKA, Y. Properties of acetolactate synthase from sulfonylurea-resistant Scirpus juncoides Roxb. var. ohwianus T. Koyama. Pestic. Biochem. Physiol., v. 77, n. 1, p. 147-153, 2003.

TELES, A. M.; BORGES, R. A. X.; HEIDEN, G. Conyza. In: Lista de espécies da Flora do Brasil. Rio de Janeiro: Jardim Botânico do Rio de Janeiro, 2013. (http://

floradobrasil.jbrj.gov.br/jabot/ floradobrasil/FB5288).

THEBAUD, C.; ABBOTT, R. J. Characterization of invasive Conyza species (Asteraceae) in Europe: quantitative trait and isozyme analysis. $\boldsymbol{A m}$. J. Bot., v. 82, n. 1, p. 360-368, 1995.

TRANEL, P. J.; WRIGHT T. R. Resistance of weeds to ALS inhibiting herbicides: what have we learned? Weed Sci., v. 50, p. 700-712, 2002.

VARGAS, L. et al. Resistência de plantas daninhas a herbicidas. Viçosa, MG: JARD Produções, 1999. 131 p.

VARGAS, L. et al. Buva (C. bonariensis) resistente ao glyphosate na Região Sul do Brasil. Planta Daninha, v. 25, n. 3, p. 573-578, 2007.

VARGAS, L. et al. Resposta de biótipos de Euphorbia heterophylla a doses de glyphosate. Planta Daninha, v. 29, p. 1121-1128, 2011. (Número Especial)

YU, Q. et al. AHAS herbicide resistance endowing mutations: Effect on AHAS functionality and plant growth. J. Exper. Bot., v. 61, n. 14, p. 3925-3934, 2010. 